\title{
Effects of GnRH and hCG Treatments for Enhancing Corpus Luteum Function to Increase Lambing Rate of Ewes Artificially Inseminated During the Non-Breeding Season
}

\author{
Naohisa ISHIDA, Midori OKADA, Kazuhide SEBATA, Mayuko MINATO and \\ Yutaka FUKUI
}

Laboratory of Animal Genetics and Reproduction, Obihiro University of Agriculture and Veterinary Medicine, Obihiro 080-8555, Japan

\begin{abstract}
Two experiments were conducted to enhance the corpus luteum (CL) function for increasing lambing rate of ewes treated with GnRH or hCG after artificial insemination (AI) during the non-breeding season. Ewes (Experiment 1: $n=102$, Experiment 2: $n=37$ ) were pretreated with a controlled internal drug release dispenser (CIDR) for 12 days and 500 IU equine chorionic gonadotropin (eCG) 1 day before CIDR removal. In Experiment 1, the ewes were treated on Day 12 (Day 0=CIDR removal): 1) Group I; GnRH (100 $\mu \mathrm{g})$, 2) Group II; hCG (500 IU), 3) Group III; 0.6\% saline (2 $\mathrm{ml})$ for control. Pregnancy and lambing rates and prolificacy were not significantly different among the groups. But, there was significant $(\mathrm{P}<0.01)$ difference in the lambing rate between parous $(27 \%)$ and non-parous (72\%) in Group I. On Day 17, plasma progesterone $\left(\mathrm{P}_{4}\right)$ levels of Group I were significantly $(\mathrm{P}<0.01)$ lower than those of Group III, but on the contrary, the plasma $\mathrm{P}_{4}$ levels of Group II were significantly $(\mathrm{P}<0.01)$ higher than those of Group III. In Experiment 2, the ewes were treated: 1) Group I; hCG (500 IU) on Day 6, 2) Group II; hCG (500 IU) on Day 9, 3) Group III; no treatment for control. Pregnancy and lambing rates and prolificacy were not significantly different among the groups, but on Days 12 and 15, the plasma $\mathrm{P}_{4}$ levels of Groups I and II were significantly $(\mathrm{P}<0.01)$ higher than those of Group III. The present results indicate that a single hCG treatment on Days 6, 9 and 12 after CIDR removal stimulates CL and increased $\mathrm{P}_{4}$ concentration, but the increased $\mathrm{P}_{4}$ levels did not reflect on the fertility of treated ewes.

Key words: Lambing, Corpus luteum, Non-breeding season, Ewe.
\end{abstract}

(J. Reprod. Dev. 45: 73-79, 1999)

$\mathbf{T}$ he necessity of corpus luteum (CL) and progesterone $\left(\mathrm{P}_{4}\right)$-secreting capacity of $\mathrm{CL}$ for the establishment of early pregnancy in domestic animals is well known [1-4]. Fertility of ewes induced estrus during the non-breeding season has varied independently with mating methods (40 to $70 \%$ in lambing rate) [5-10]. Wilmut et al. [4] suggested that if the CL function was inadequate, a substantial loss in fertility occurred. Additionally, several

Accepted for publication: September 25, 1998

Correspondence: Y. Fukui researchers have reported a direct association between progesterone $\left(\mathrm{P}_{4}\right)$ concentrations following breeding and embryonic development and pregnancy maintenance $[1,11,12]$.

The gonadotrophin releasing hormone $(\mathrm{GnRH})$ modulates the secretion of luteinizing hormone (LH) and follicle stimulating hormone (FSH), and the endogenous surge of LH during estrus is needed for ovulation and luteinizing of granulosa and theca cells to form luteal cells for subsequent progesterone secretion [13]. The human chorionic gonadotropin (hCG) treatment is known to increase 
$\mathrm{P}_{4}$ and total weight of CL $[14,15]$, and the responses are apparently due to a direct effect of this gonadotropin on hypertrophy and (or) to increase blood flow to the CL $[16,17]$.

Fukui et al. [18] attempted to improve the fertility in ewes during the non-breeding season by administrating GnRH at estrus and administrating hCG immediately after mating or Days 10 to 12 after mating, but all the treatments did not achieve further improvement of fertility. Kittok et al. [14] improved the fertility in lactating ewes by administrating 250 IU hCG on Days 11, 12, and 13 after mating. Nephew et al. [15] reported that treatment with hCG on Day 11.5 after the onset of estrus stimulated uterine secretions and conceptus growth sufficiently to influence pregnancy rates.

Up-to-date, a single or multiple injection of hCG at the late luteal phase after mating has resulted in contravercial effects on conception rate in sheep. Also, there is little information on a single injection of GnRH at the late luteal phase in inseminated ewes during the non-breeding season. As GnRH modulates the secretion of $\mathrm{LH}$, a single injection of GnRH or hCG at the late luteal phase needs to examine the effect on lambing rate in anestrous ewes.

The purpose of this study was to enhance the CL function for increasing lambing rate by a single injection of $\mathrm{GnRH}$ or hCG after artificial insemination (AI) in ewes induced estrus during the non-breeding season. In Experiment 1, effect of a single injection of GnRH or hCG at the late luteal phase (Day 12 after controlled internal drug release dispenser (CIDR) removal) was examined. In Experiment 2, effect of a single injection of hCG at the early luteal phase (Day 6 or 9 after CIDR removal) was examined. Pregnancy and lambing rates, $\mathrm{P}_{4}$ concentrations, and prolificacy were investigated in both experiments.

\section{Materials and Methods}

The present experiments were conducted at the Shibetsu Sheep Farm (Experiment 1; 1996) during May to June, and at a private sheep farm, "Japan Lamb" (Experiment 2; 1997) during June to July, in Hokkaido, Japan. All ewes were pretreated with a CIDR for 12 days and 500 IU equine chorionic gonadotrophin (eCG) one day before CIDR removal.

\section{Experiment 1}

Forty-five parous and fifty-seven non-parous Suffolk ewes were divided into 3 groups after AI. The ewes were treated by an intramuscular injection of $100 \mu \mathrm{g}$ GnRH (Conceral: Takeda Chemical Industries Co., Ltd. Japan) (Group I: n=34) or 500 IU hCG (Gonatropin: Teikoku-zouki Co., Japan) (Group II: $\mathrm{n}=34$ ) or $2 \mathrm{ml}$ of $0.6 \%$ saline (Group III: $\mathrm{n}=34$ ) as a control on Day 12 (Day $0=$ the day of CIDR removal) after CIDR removal. AI was carried out at 44 to $54 \mathrm{~h}$ after CIDR removal without estrus detection, by an intrauterine AI with frozen-thawed semen using a laparoscope. Semen was collected by an artificial vagina from two mature Suffolk rams and was frozen in $0.2 \mathrm{ml}$ pellets, as previously described [19], and thawed at $37 \mathrm{C}$ in a water bath immediately before insemination. Post-thawing motility ranged from 40 to $50 \%$. The insemination dose was $0.2-0.4 \mathrm{ml}$ containing $70 \times$ $10^{6}$ total sperm per uterine horn. Jugular venus blood $(5 \mathrm{ml})$ was collected for determination of $\mathrm{P}_{4}$ on Days 2 (at the time of AI), 12, 17 and 22 from the half number of ewes $(n=17)$ in each group. Plasma was immediately separated and stored at -20 $\mathrm{C}$ until measurement of $\mathrm{P}_{4}$ with an enzyme-immunoassay (EIA) [20]. On Day 22, ewes with more than $1 \mathrm{ng} / \mathrm{ml}$ of $\mathrm{P}_{4}$ levels were considered to be pregnant [21] and thereafter pregnancy was confirmed by a real-time ultrasonic scanning at Day 60 [22].

\section{Experiment 2}

Thirty-seven parous Suffolk ewes were divided into 3 groups after AI. The ewes were treated by an intramuscular injection of 500 IU hCG on Day 6 (Group I: $n=13$ ), or on Day 9 (Group II: $n=12$ ) and no treatment for control (Group III: $n=12$ ). AI was carried out at 35 to $38 \mathrm{~h}$ after CIDR removal without estrus detection, by a cervical AI with fresh-undiluted semen. Semen was collected by an artificial vagina from a mature Suffolk ram, and motility ranged 80 to $90 \%$. The insemination dose was $0.2-0.3 \mathrm{ml}$ containing $600 \times 10^{6}$ total sperm per ewe. Jugular venous blood was collected for determination of $\mathrm{P}_{4}$ on Days 2 (at the time of $\mathrm{AI}$ ), $6,9,15,18$, and 21 in all treated ewes of each group. Plasma was separated and stored at $-20 \mathrm{C}$ for $\mathrm{P}_{4}$ measurement, as in Experiment 1. 


\section{Statistical analysis}

Data of pregnancy and lambing rates in both experiments were analyzed by chi-square test. The plasma $\mathrm{P}_{4}$ concentrations and prolificacy in both experiments were analyzed to compare between each treatment and control groups by the Student's $t$-test.

\section{Results}

\section{Experiment 1}

Four ewes (Group I-one ewe, Group II-two ewes, Group III-one ewe) were excluded from the data due to death before lambing.

Results of pregnancy and lambing rates and prolificacy are shown in Table 1 . The pregnancy and lambing rates in Groups I (55.9\%, 51.5\%) and II $(61.8 \%, 59.4 \%)$ tended to be lower than those of the control (Group III: 67.8\%, 63.6\%), but there were no significant difference. Prolificacy was also not significantly different among the groups. There was a significant difference $(\mathrm{P}<0.01)$ in the lambing rates between parous $(26.7 \%)$ and non-parous $(72.2 \%)$ ewes in Group I (Table 2).
As shown in Fig. 1, the plasma $\mathrm{P}_{4}$ levels of Group II were significantly $(\mathrm{P}<0.05)$ higher than those of control ewes (Group III). On Day 22, the plasma $\mathrm{P}_{4}$ levels of Group I were significantly $(\mathrm{P}<0.05)$ lower than those of control ewes (Group III). The plasma $\mathrm{P}_{4}$ levels of pregnant ewes on Days 12,17 and 22 were significantly $(\mathrm{P}<0.01)$ higher when compared with those of non-pregnant ewes (Fig. 2).

\section{Experiment 2}

Three ewes in Group III were dead before pregnancy diagnosis, and were excluded from pregnancy and lambing data.

Results of pregnancy, lambing and prolificacy are shown in Table 3. The pregnancy and lambing rates in Group II $(25.0 \%, 25.0 \%)$ tended to be lower than those in Group III $(44.4 \%, 44.4 \%)$, but there were no significant differences among the groups.

As shown in Fig. 3, the plasma $\mathrm{P}_{4}$ levels of Groups I and II on Days 12 and 15 were significantly $(\mathrm{P}<0.01)$ higher than those in Group III. The plasma $\mathrm{P}_{4}$ levels in ewes treated with hCG on Day 9 (Group II) increased rapidly after treatment with the highest $\mathrm{P}_{4}$ value on Day 12 , but the plasma $\mathrm{P}_{4}$ levels beyond Day 15 declined sharply to the sig-

Table 1. Pregnancy and lambing rates of ewes treated with GnRH, hCG or saline on Day 12 after CIDR removal (Experiment 1)

\begin{tabular}{lcccc}
\hline Group & $\begin{array}{c}\text { No. of ewes } \\
\text { treated }\end{array}$ & $\begin{array}{c}\text { No. of ewes } \\
\text { pregnant } \\
(\%)^{* 1}\end{array}$ & $\begin{array}{c}\text { No. of ewes } \\
\text { lambed } \\
(\%)^{* 2}\end{array}$ & Prolificacy \\
\hline I (GnRH) & 34 & $19(55.9 \%)$ & $17(51.5 \%)$ & 1.35 \\
II (hCG) & 34 & $21(61.8 \%)$ & $19(59.4 \%)$ & 1.32 \\
III (Saline) & 34 & $23(67.6 \%)$ & $21(63.6 \%)$ & 1.52 \\
\hline Total & 102 & $63(61.8 \%)$ & $57(58.2 \%)$ & 1.40 \\
*1 A pregnancy test was performed by a real-time ultrasonic scanning at \\
60 days after artificial insemination. \\
*2 Four treated ewes (Group I-1 ewe, Group II-2 ewes, Group III-1 ewe) \\
were dead before lambing, and they were excluded from lambing data.
\end{tabular}

Table 2. Lambing rates of parous and non-parous ewes (Experiment 1)

\begin{tabular}{crrrc}
\hline \multirow{2}{*}{ Ewe } & \multicolumn{4}{c}{ No. of ewes lambed/treated* (\%) } \\
\cline { 2 - 5 } & \multicolumn{1}{c}{$\mathrm{I}(\mathrm{GnRH})$} & \multicolumn{1}{c}{ II (hCG) } & \multicolumn{1}{c}{ III (saline) } & Total \\
\hline Parous & $4 / 15(26.7 \%)^{\mathrm{a}}$ & $10 / 15(66.7 \%)$ & $9 / 15(60.0 \%)$ & $23 / 45(51.1 \%)$ \\
Non-parous & $13 / 18(72.2 \%)^{\mathrm{b}}$ & $9 / 17(52.9 \%)$ & $12 / 18(66.7 \%)$ & $34 / 53(64.2 \%)$ \\
\hline
\end{tabular}

* Four treated ewes (Group I-1 ewe, Group II-2 ewes, Group III-1 ewe) were dead before lambing.

$\mathrm{a}-\mathrm{b}$ : $\mathrm{P}<0.01$. 
nificantly lower $(\mathrm{P}<0.01)$ levels than that of the control ewes (Group III).

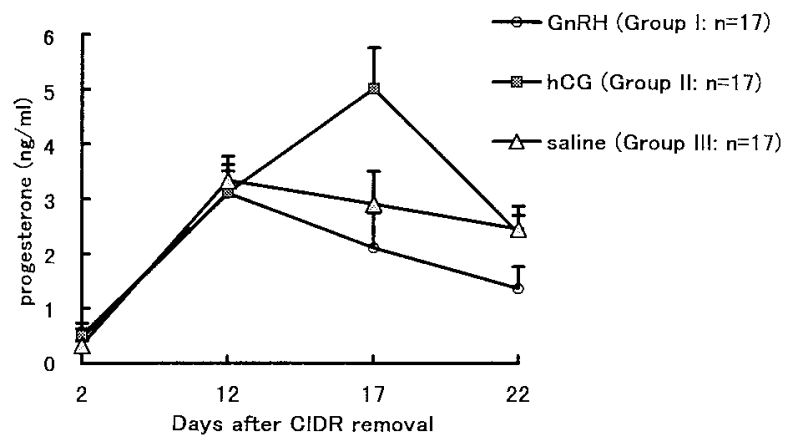

Fig. 1. The mean concentrations of plasma progesterone $\left(\mathrm{P}_{4}\right)$ of ewes treated with GnRH (Group I), hCG (Group II) or saline (Group III) in Experiment 1. All values are mean \pm SEM.

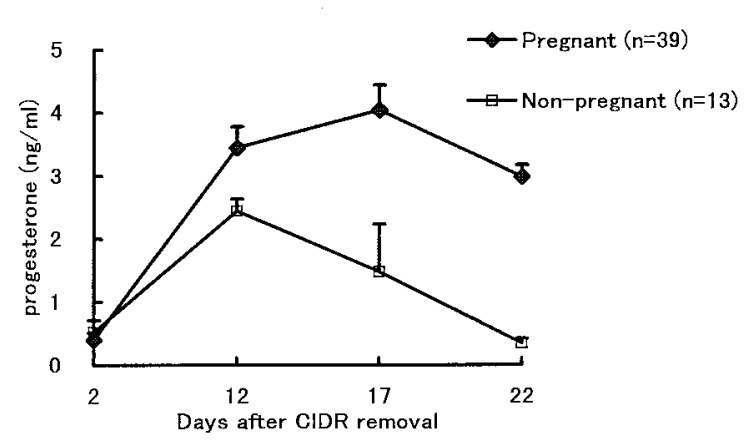

Fig. 2. The mean concentrations of plasma progesterone $\left(\mathrm{P}_{4}\right)$ from pregnant and non-pregnant ewes in Experiment 1. Pregnant ewes had more than 2 $\mathrm{ng} / \mathrm{ml} \mathrm{P}_{4}$ levels on Day 22. All values are mean \pm SEM.

\section{Discussion}

In Experiment 1, the effect of a single injection of GnRH or hCG on fertility of ewes at Day 12 after CIDR removal was investigated. However, the fertility of ewes was not improved. In the GnRH-treated group (Group I), the lambing rate of parous ewes was significantly lower than that of non-parous ewes. In the GnRH-treated ewes, the plasma $\mathrm{P}_{4}$ levels on Day 17 tended to be low and on Day 22 were significantly lower than the control ewes. Especially, the plasma $\mathrm{P}_{4}$ levels in parous ewes treated with GnRH declined immediately after treatment to Day 22 (data not shown). Many authors reported that GnRH treatment reduced plasma $\mathrm{P}_{4}$ concentration [23-26], and the present result has supported this phenomenon (Fig. 1). On the contrary, there are reports that GnRH

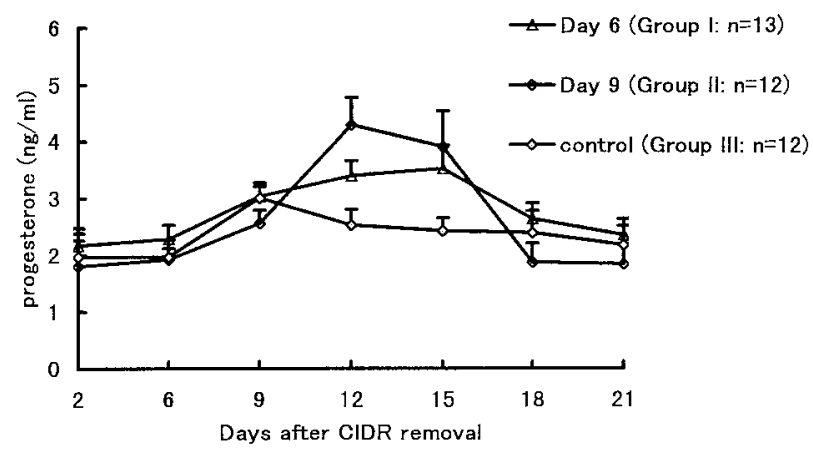

Fig. 3. The mean concentrations of plasma progesterone $\left(\mathrm{P}_{4}\right)$ in ewes treated with hCG on Day 6 (Group I), Day 9 (Group II) and no treatment (Group III) in Experiment 2. All values are mean \pm SEM.

Table 3. Pregnancy and lambing rates of ewes treated with hCG on Days 6, or 9 after CIDR removal (Experiment 2)

\begin{tabular}{lcccc}
\hline Group & $\begin{array}{c}\text { No. of ewes } \\
\text { treated }\end{array}$ & $\begin{array}{c}\text { N. of ewes } \\
\text { pregnant } \\
(\%)^{* 1 * 2}\end{array}$ & $\begin{array}{c}\text { No. of ewes } \\
\text { lambed } \\
(\%)^{* 2}\end{array}$ & Prolificacy \\
\hline I (Day 6) & 13 & $6(46.2 \%)$ & $6(46.2 \%)$ & 1.50 \\
II (Day 9) & 12 & $3(25.0 \%)$ & $3(25.0 \%)$ & 1.00 \\
III (Control) & 12 & $4(44.4 \%)$ & $4(44.4 \%)$ & 1.25 \\
\hline Total & 37 & $13(38.2 \%)$ & $13(38.2 \%)$ & 1.31 \\
\hline
\end{tabular}

*1 A pregnancy test was performed by a real-time ultrasonic scanning at 60 days after artificial insemination.

*2 Three ewes in Group III were dead before a pregnancy test, and they were excluded from the pregnancy and lambing data. 
treatment increased $\mathrm{P}_{4}$ concentrations [27, 28]. Macmilan et al. [29] found that the effect of GnRH on $\mathrm{P}_{4}$ production varied with the stages of the estrous cycle in cows. Although a clear reason for the low lambing rate in parous ewes treated with $\mathrm{GnRH}$ is unknown in the present study, GnRH treatment also induces a high level of plasma estradiol-17 $\beta\left(\mathrm{E}_{2}\right)$ in cows [24] and the following luteolysis induced by the high $\mathrm{E}_{2}$ levels may be one reason for the decrease of $\mathrm{P}_{4}$ levels and the low fertility in GnRH-treated ewes. However, the difference in the lambing rates between parous and non-parous ewes could not be explained from the present study.

In Experiment 1, the plasma $\mathrm{P}_{4}$ levels on Day 17 in ewes treated with hCG were significantly higher than those of control ewes (Fig. 1). It has been reported that hCG treatment increased plasma $\mathrm{P}_{4}$ concentration in cows and ewes, and enhanced lambing rate [14, 15, 30-32]. In the present study, although the plasma $\mathrm{P}_{4}$ levels increased, lambing rates were not improved. Additionally, the decrease of the proportions between pregnancy and lambing was smallest $(2.4 \%)$ in ewes treated with hCG compared with those in other groups, although the difference was not significant. The fertility may not be improved by the hCG administration at the late luteal phase (Day 12), because the plasma $\mathrm{P}_{4}$ levels on Day 12 was already significantly lower in non-pregnant ewes as compared with that of pregnant ewes (Fig. 2). Therefore, we extended to investigate the effects of hCG treatment at the early luteal stage (Day 6 or 9 ) in Experiment 2.

In Experiment 2, fertility was also not improved, and the lambing rate of ewes treated with hCG on Day 9 tended to be low. The plasma $\mathrm{P}_{4}$ levels treated with hCG on Day 9 increased on Day 12 with the highest levels, and declined to Days 18 and 21, immediately (Fig. 3). An increased of plas- ma $\mathrm{P}_{4}$ concentration observed in the ewes treated with hCG on Day 9 might be detrimental effect on $\mathrm{CL}$ function and/or embryonic development. On the other hand, the plasma $\mathrm{P}_{4}$ levels in ewes treated with hCG on Day 6 gradually increased to Day 15 after treatment. Lucy et al. [24] reported in cattle that improved fertility may be associated with delayed or slow rising of concentrations of serum progesterone after ovulation. However, the present study failed to improve the fertility of inseminated ewes even with the slow increase of the plasma $\mathrm{P}_{4}$ levels after hCG treatment on Day 6. The discrepancy should be clarified in the future study. For a future study, it would also be worthy to investigate the effect of hCG at Day 6 or earlier stage after CIDR removal using a large number of ewes. In the present study, a single 500 IU hCG was employed. Therefore, administration methods of hCG (dose and injection number) as well as the injection timing at the induced luteal phase should be involved in a future study.

In conclusion, a single GnRH or hCG treatment on Day 12 did not improve the fertility of ewes treated during the non-breeding season, although hCG administration stimulated CL to increase plasma $\mathrm{P}_{4}$ concentration. Also, hCG treatment on Days 6 and 9 after CIDR removal did not improve the fertility.

\section{Acknowledgments}

We thank "Yamato Farm", Shibetsu-city and "Japan Lamb", Otofuke-cho, Hokkaido, Japan for supply of the animals and facilities used for this study. This work was supported by a grant from the Hokkaido Foundation for the Promotion of Scientific and Industrial Technology (Hokscitec), Japan.

\section{References}

1. Erb RE, Garverick HA, Randel RD, Brown BL, Callahan CJ. Profiles of reproductive hormones associated with fertile and non-fertile inseminations of daily cows. Theriogenology 1976; 5: 227-242.

2. Bulman DC, Lamming GE. Milk progesterone levels in relation to conception, repeat breeding and influence acyclicity in daily cows. J Reprod Fertil
1978; 54: 447-458.

3. Hansel W, Convey EM. Physiology of the estrous cycles. J Anim Sci 1983; 57 (Suppl 2): 404.

4. Wilmut I, Sale DI, Ashworth CJ. The influence of variation in embryo stage and maternal hormone profiles embryo survival in farm animals. Theriogenology 1985; 23: 107-119. 
5. Fukui Y, Kobayashi M, Ono H. Effects of injection time of pregnant mare's serum gonadotrophin and individual rams on fertility of ewes in a trial of out-of-season breeding. Jpn J Anim Reprod 1985; 30: 108-116.

6. Fukui Y, Kobayashi M, Kojima M, Ono H. Effects of time of PMSG and fixed-time GnRH injections on estrus incidence and fertility in physiologically different ewes pre-treated with progesterone-impregnated vaginal sponge during the non-breeding season. Theriogenology 1985; 24: 631-641.

7. Fukui Y, Tsubaki M, Kobayashi M, Ono H. Mating behavior of ram on ewes induced estrus during the non-breeding season. Jpn J Anim Reprod 1986; 32: 195-201.

8. Kobayashi M, Fukui Y, Tetsuka M, Ono H. Effects of time of PMSG injection on estrous incidence and lambing rate in ewes treated during the nonbreeding season. Jpn J Anim Reprod 1986; 32: 32-35 (In Japanese).

9. Fukui Y, Tetsuka M, Akaike M, Machiyama K, Ono H. Effects of types of vaginal sponge impregnated with progesterone on estrous induction and lambing rate in seasonally anestrous ewes. Jpn J Anim Reprod 1987; 33: 181-187.

10. Fukui Y, Akaike M, Anzai H, Ono H. Effect of timing of injection with pregnant mare's serum gonadotrophin on fixed-time artificial insemination of seasonally anoestrous ewes. J Agric Sci, Camb 1989; 113: 361-364.

11. Lukaszewska J, Hansel W. Corpus luteum maintenance during early pregnancy in the cow. J Reprod Fertril 1980; 59: 485-493.

12. Thompson FJ, Clekis T, Kiser TE, Chen HJ, Smith CK. Serum progesterone concentratons in pregnant and nonpregnant heifers and after gonadotropin releasing hormone in luteal phase heifers. Theriogenology 1980; 14: 407-417.

13. Henderson KM. Gonadotrophic regulation of ovarian activity. British Med Bull 1979; 35: 161-166.

14. Kittok RJ, Stellflug JN, Lowry SR. Enhancing progesterone and pregnancy rate after gonadotrophin administration in lactating ewes. J Anim Sci 1983; 56: 652-655.

15. Nephew KP, Cardenas H, Mcclure KE, Ott TV, Bazer FW, Pope WF. Effects of administration of human chorionic gonadotrophin or progesterone before maternal recognition of pregnancy on blastocyst development and pregnancy in sheep. J Anim Sci 1994; 72: 453-458.

16. Farin CE, Moeller CL, Mayan H, Gambon F, Sawyer HR, Niswender GD. Effects of luteinizing hormone and human chrionic gonadotropin on cell populations in the ovine corpus luteum. Biol Reprod 1988; 38: 413-421.

17. Niswender GD, Reimers JJ, Diekman MA, Nett TM. Blood flow: A mediator of ovarian function.
Biol Reprod 1976; 14: 64-81.

18. Fukui Y, Kobayashi K, Hirose Y, Ono H. Effects of GnRH and hCG injections on lambing rate of estrus-induced ewes during the non-breeding season. Jpn J Anim Reprod 1991; 37: 243-250.

19. Salamon S, Visser D. Tris-based dilluents and thawing solution on survival of ram spermatozoa frozen by the pellet method. Aust J Biol Sci 1972; 25: 605-618.

20. Prakash BS, Meyer HHD, Schallenber E, Vandewill DFM. Development of a sensitive enzymeimmunoassay (EIA) for progesterone determination in unextracted bovine plasma using the second antibody technique. J Steroid Biol 1987; 28: 623-627.

21. Robertson HA, Sarda IR. A very early pregnancy test for mammals: its application to the cow, ewe and sow. J Endocr 1971; 49: 407-419.

22. Willkins JF, Fowler DG, Piper LR, Bindon BM. Observations on litter-size and reproductive wastage using ultrasonic scanning. Proc Aust Soc Anim Prod 1982; 14: 637.

23. Ford SP, Stormshak F. Bovine ovarian and pituitary responses to PMS and GnRH adminsitered during metestrus. J Anim Sci 1978: 46: 1701-1706.

24. Lucy MC, Stevenson JS. Serum progesterone and estradiol-17 $\beta$ following GnRH and artificial insemination in Holstein cows. J Dairy Sci 1985 (Suppl 1); 68: 178.

25. Lucy MC, Stevenson JS. Gonadotrophin-releasing hormone at estrus: luteinizing hormone, estradiol, and progesterone during the periestrual and postinsemination periods in daily cattle. Biol Reprod 1986; 35: 300-311.

26. Ryan DP, Kopel E, Boland MP, Godke RA. Pregnancy rates in daily cows following the administration of a GnRH analogue at the time of artificial insemination or at mid-cycle post insemination. Theriogenology 1991; 36: 367-377.

27. Kittok RJ, Britt JH, Convey EM. Endocrine response after GnRH in luteal phase cows and cows with ovarian follicular cysts. J Anim Sci 1973; 37: 985-989.

28. Milvae RA, Murphy BD, Hansel W. Prolongation of the bovine estrous cycle with a gonadotrophinreleasing hormone analog. Biol Reprod 1984; 31: 664-760.

29. Macmillan KL, Day AM, Taufa VK, Gibb M, Pece MG. Effects of an agonist of gonadotrophin releasing hormone in cattle. I. Hormone concentrations and oestrous cycle length. Anim Reprod Sci 1985; 8: 203-212.

30. Moses D, Martinez AG, Iorio G, Valcarcel A, Ham A, Pessi H, Castanon R, Macia A, delas Heras MA. A large-scale program in laparoscopic intrauterine insemination with frozen-thawed semen in Australian Merino sheep in Argentine Patagonia. 
Theriogenology 1991; 48: 651-657.

31. Lewis GS, Caldwell DW, Rexroad CE, JR. Effects of gonadotrophin-releasing hormone and human chorionic gonadotrophin on pregnancy rate in daily cattle. J Dairy Sci 1990; 73: 66-72.
32. Breuel KF, Spitzer JC, Thompson CE, Breuel JF. First-service pregnancy rate in beef heifers as influenced by human chorionic gonadotrophin administration before and/or after breeding. Theriogenology 1990; 34: 139-145. 